\title{
THE IMPACT OF INFLATION, CERTIFICATE OF BANK INDONESIA, AND EXCHANGE RATE OF IDR/USD ON THE INDONESIA COMPOSITE STOCK PRICE INDEX
}

\author{
Margarita Ekadjaja ${ }^{1}$, Daisy Dianasari ${ }^{2}$ \\ ${ }^{1}$ Jurusan Manajemen,Universitas Tarumanagara Jakarta \\ rita_e11510@yahoo.com \\ ${ }^{2}$ Jurusan Manajemen,Universitas Tarumanagara Jakarta \\ daisydianasari@gmail.com
}

\begin{abstract}
This research is done with the aim to know whether some macroeconomic variables, which are inflation rate, certificate of Bank Indonesia (SBI) rate, and exchange rate of IDR/USD have an impact on the movement of the composite stock price index (IHSG) at the Indonesia stock exchange (BEI) partially and simultaneously in the period of 2006-2014. The research population is inflation rate, SBI rate, and exchange rate of IDR/USD. Data analysis in this research is multiple regression by using time series monthly data of 2006-2014. Research results show that partially inflation rate gives positive significant impact on IHSG, SBI rate has negative significant impact on IHSG, and exchange rate of IDR/USD has positive significant impact on IHSG. Simultaneously it shows that inflation, SBI rate, and exchange rate of IDR/USD have an impact on IHSG at BEI to the period of year 2006 2014. Those variables affect IHSG by 58,74\%, while other variables affect IHSG by 41,26\%. That information can be used by investors to make decision on their investment.
\end{abstract}

Keywords: inflation, SBI, exchange rate, IHSG, BEI.

\section{Introduction}

Background

Basically, a corporation is operating to get profit as one of important resources to sustain its operation. However, sometimes profit and internal fund are not sufficient to fund the operation, forcing the company to get external funds, either from the public, other corporations, or intermediary funding institutions such as banks.

One of the funding institutions is the capital market which is allowing a corporation to get funding (Jogiyanto, 2003). Banks and the capital market play an important role in the financial system and macro-economic of a country, and both have a similar sensitivity against political, social and safety situation locally and globally (Gregory,2000). Performance of capital market is measured by the stock price movement and the volume of transaction.

Muradoglu,et.al.(2001) explained that a lot of researches have been done to understand the relation between share price and macro-economic variables, e.g. by Chen, et al. (1986) and Fama (1981). Results of their researches showed that share price is affected by macro-economic fluctuation. Several variables of macro-economic used are inflation rate, SBI rate and exchange rate of IDR/USD.

Sukirno (2004:27) defined that inflation is the general process of price increase in an economy. Case dan Fair (2002:216) defined that inflation is a global increase of price level. Thus, inflation is a phenomenon of continuous price increase of several goods. Case dan Fair (2002), discovered positive relation between inflation and share price. Higher inflation rate will cause higher price of goods and services, and at the end will also increase the profit and share price.

Case dan Fair (2002:635) defined that interest rate is a yearly interest payment of a loan, in the form of percentage of interest amount which is received in a year divided by the loan amount. According to Sunariyah (2006:80) interest rate is the price of a loan. SBI in principle is securities in rupiah issued by the Indonesia central bank as short term loans and sold with discount price (Siamat, 2005:52). According to Tandelilin (2010), interest rate and share price have a negative 
relation. High interest rate will affect the present value of a company cash flow. Thus, investment chances are not interesting. High interest rate will increase the cost of capital for the corporation and will also increase expected returns from investors.

According to Miskhin and Eakins (2000:331), the value of a currency against other currency is called exchange rate or forex. According to Keown (2002:737), exchange rate is the price of foreign currency stated in terms of domestic home currency. Based on the above definition, we can say that exchange rate is a relative price of one currency which is declared in the other country's currency. Widiyarsih and Anti (2009), explained that exchange rate gives a significantly negative impact on the Indonesia composite stock price index (IHSG).

According to Jones (2002), IHSG is an index of all sharers in the market, and designed to privide information about market share movement as a consideration for the investors who want to invest in buying shares. Thus, IHSG is a consolidation of all shares in the market which is affected by market capital of a share, and which is designed to provide infromation about share price movement, measure the performance of a share in the stock exchange, and become a consideration for investors in investing in the stock.

Venus and Huzaimi (2004) in their study found there is a cause and effect relation between foreign exchange rate and stock price. In the study done by Malaysia and Thailand during the economic crisis in 1997-1998, they also found the influence of foreign exchange to the stock price.

Aydemir and Dermihan (2009) in their study also found negative impacts of foreign exchange to the whole Turkish stock price index. Study done by Gupta et.al (1997) in Sri Maryanti (2009) found that exchange rate has a causal impact that is not significant to the stock price.

Based on the above, the main objective of this research is to find whether there is a relation between inflation rate, SBI rate and exchange rate of IDR/USD to IHSG at BEI within the period of 2006-2014.

\section{Problems Identification}

a. Is there any relation between inflation rate and IHSG at BEI?

b. Is there any relation between SBI rate and IHSG at BEI?

c. Is there any relation between exchange rate of IDR/USD and IHSG at BEI ?

d. Is there any relation between inflation rate, SBI rate, and exchange rate of IDR/USD simultaneously and IHSG at BEI?

\section{Purpose of this study}

a. To find out if there is an impact of inflation on IHSG at BEI.

b. To find out if there is an impact of SBI rate on IHSG at BEI.

c. To find out if there is an impact of exchange rate of IDR/USD on IHSG at BEI.

d. To find out if there is an impact of inflation, SBI rate, and exchange rate of IDR/USD simultaneously on IHSG at BEI.

\section{Methodology}

\section{Subject and object}

The research subject is where all data sources of research variables are obtained. Subject of this study is data from the Indonesia stock exchange (BEI) in the period of 2006-2014 using time series monthly data. The research objects cover the composite stock price index (IHSG) at BEI, 
inflation rate, certificate of Bank Indonesia (SBI) rate, and exchange rate of IDR/USD at BEI in the period of $2006-2014$.

\section{Population and sampling method}

The population in this study is all data of inflation rate, SBI rate, exchange rate of IDR/USD at Bank Indonesia (BI), and IHSG at the Indonesia stock exchange (BEI) within the period of 2006 - 2014. The samples are the mean of inflation rate, SBI rate, exchange rate of IDR/USD and IHSG at BEI in monthly periods of 2006-2014. The sampling technique used in this study is non probability sampling.

\section{Operational variables}

Variables used in this study are classified into dependent variables and independent variables. Dependent variables are variables that will be predicted and explained in the future, while independent variables are variables that are used to forecast or explain the existence of independent variables in the future. The independent variables are:

a. Inflation: a phenomenon of continuous price increase of some commodities. Inflation is an instrument to measure the economic stability of an area or region which is showing the growth of people's buying power and fixed income. Inflation is noted as X1. Measurement:

$$
\text { Inflation }=(\text { Average of inflation value of each month })
$$

b. Certificate of Bank Indonesia (SBI) is a certificate issued by the Indonesian central bank (BI) to certify short term debts (1-2 months) with an interest/discount. SBI rate for 1 (one) month is determined by the auction at BI. SBI rate is noted as X2. Measurement:

Certificate of Bank Indonesia (SBI) rate = (Average of SBI rate each month)

c. IDR/USD foreign exchange rate is the amount of Indonesian Rupiah which has to be used to get one unit of USD. Currency exchange rate between IDR/USD is noted as X3. Measurement:

Exchange rate of IDR/USD = (Average of BI IDR/USD exchange rate of each month $)$

The dependent variable used in this study is IHSG at BEI, which is an indicator of overall share price at BEI that is influenced by market capitalization of each share. IHSG is noted as Y. Measurement:

$$
\text { Composite share price index (IHSG) = (average of IHSG of each month) }
$$

\section{Data Analysis Technique}

This study uses multiple regression analysis. Using multiple regression validity, data must be tested by classical assumption. Since the data used are in a time series, therefore the classical test was done with multi co-linearity, autocorrelation, and normality tests. The variable data were processed by computer with Eviews 6.0 software.

\section{Classical assumption test}

According to Aritonang (2002) before a regression analysis can be used for forecasting, a classical assumption test needs to be done for the background of the multiple regression analysis.

a. Multicollinearity test

According to Aritonang (2002) the purpose of multicollinearity test is to know if there is a significant or perfect correlation between $>2$ independent variable which is close to 1 
or -1 .

Multicollinearity test is done using Eviews 6.0. Software with the intention to see how the relation of each variable. Multicollinearity presence can be detected by looking at matrix correlation. If the matrix data correlation is more than 0,8 , then the data has multicollinearity problem, and if the correlation is less than 0,8 , it means that data has no problem with multicollinearity (Ajija,et.al: 2011). While according to Widarjono (2005) multicollinearity has problem if the matrix correlation of variables exceeds 0,9 .

b. Autocorrelation test

According to Aritonang (2002), the purpose of the auto-correlation test is to check if there is a significant relation between two data which are close one another. Autocorrelation can be seen from Durbin-Watson coefficient. If $-2 \leq \mathrm{D}-\mathrm{W} \leq 2$, it means there is no autocorrelation (Ajija,et.al: 2011). A good regression model is supposed to have no autocorrelation.

\section{Multiple regression analysis}

Multiple regression analysis is used to know how big the impact of independent variables on the dependent variables is where variable independents are used as an instrument to predict the dependent variables. Multiple regression analysis is used if independent variables are more than one. In this study there are four variables which consist of one dependent variable and three independent variables. According to Ajija, et.al (2011), multiple regression equation that will be formed in this research is as follows:

$$
\mathrm{Y}=\mathrm{a}+\mathrm{b} 1 \mathrm{X} 1+\mathrm{b} 2 \mathrm{X} 2+\mathrm{b} 3 \mathrm{X} 3+\mathrm{e}
$$

Remarks:

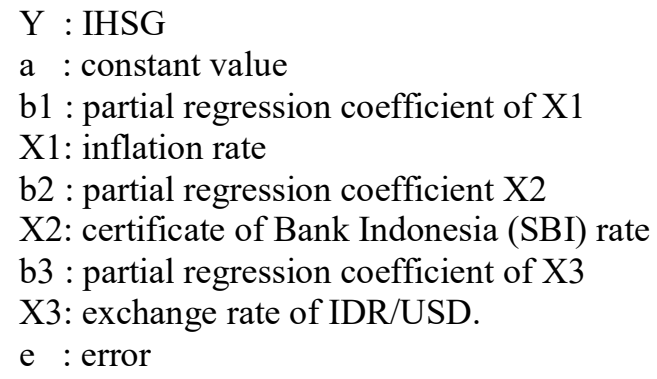

\section{Hypothesis Test}

After doing classical assumption test and multiple regression equation, the next step is hypothesis tests which are done to know whether the independent variables are affecting significantly and can be used as predictors of the dependent variable or not.

The hypothesis tests are:

a. T Test

$\mathrm{T}$ Test is used by testing hypothesis 1,2 , and 3 that were already defined before. $\mathrm{T}$ Test is used to test partially regression coefficient, to test whether there is a significant impact from one independent variable to the dependent variable if the other independent variables are assumed as constant.

b. F Test

F Test is used by testing hypothesis 4 to test regression coefficient together, which is to 
test whether there is significant impact of all independent variables all together on the dependent variable.

\section{Analysis Report and Discussion} Analysis Report

To reach the target of this research includes testing analysis of all classical assumptions by using regression model of multicollinearity test, auto-correlation test, and normality test. By using computer software Eviews 6.0, this research used 3 independent variables : inflation rate, certificate of Bank Indonesia (SBI) rate, and exchange rate of IDR/USD, while the dependent variable used is IHSG.

\section{Classical Assumption test}

a. Multicollinearity test

By using Eviews 6.0 software,herewith the output which is showing the relation between each variable :

Table 3.1 Co-relation among variables

\begin{tabular}{ccccc}
\hline & IHSG & INFLATION & SBI & FOREX \\
\hline IHSG & 1.000000 & -0.480145 & -0.683995 & 0.359322 \\
\hline INFLATION & -0.480145 & 1.000000 & 0.843921 & 0.040485 \\
\hline SBI & -0.683995 & 0.843921 & 1.000000 & -0.036098 \\
\hline FOREX & 0.359322 & 0.040485 & -0.036098 & 1.000000 \\
\hline \multicolumn{4}{r}{ Source: } & Data analysis using computer software eviews 6.0
\end{tabular}

Table 3.1 shows the result of multicollinearity test. It shows that the correlation matrix above is not higher than 0.9 or still in the range of 0.8 , It means that the data can be used for this study.

b. Autocorrelation test

By using Eviews 6.0 software, the output of auto-correlation test is as follows:

Table 3.2 Autocorrelation test result

Dependent Variable: IHSG

Method: Least Squares

Date: 03/12/17 Time: 09:01

Sample: 2006M01 2014M12

Included observations: 108

\begin{tabular}{crrrl}
\hline Variable & Coefficient & Std. Error & t-Statistic & Prob. \\
\hline C & 3743.575 & 807.7618 & 4.634504 & 0.0000 \\
\hline INFLATION & 9354.039 & 4212.607 & 2.220487 & 0.0286 \\
\hline SBI & -60375.29 & 7908.129 & -7.634585 & 0.0000 \\
\hline FOREX & 0.341240 & 0.067557 & 5.051153 & 0.0000 \\
\hline
\end{tabular}

\begin{tabular}{lrll}
\hline R-squared & 0.598984 & Mean dependent var & 3117.485 \\
\hline Adjusted R-squared & 0.587417 & S.D. dependent var & 1240.211 \\
\hline S.E. of regression & 796.6206 & Akaike info criterion & 16.23497 \\
\hline Sum squared resid & 65998863 & Schwarz criterion & 16.33431 \\
\hline Log likelihood & -872.6883 & Hannan-Quinn criter. & 16.27525 \\
\hline F-statistic & 51.78051 & Durbin-Watson stat & 0.080965 \\
\hline Prob(F-statistic) & 0.000000 & & \\
\hline
\end{tabular}

Source: Data analysis using computer software eviews 6.0 
From table 3.2 above, the value of Durbin-Watson coefficient is 0,080965 . It shows that the Durbin-Watson coefficient is within the interval of $-2 \leq \mathrm{D}-\mathrm{W} \leq 2$, which means that there is no autocorrelation. Thus, the variables and regression equation can be used in the testing process and building the regression model.

\section{Multiple regression analysis}

From table 3.2, the multiple regression equation for this research is shown below:

$$
\begin{aligned}
& \mathbf{Y}=\mathbf{3 7 4 3 . 5 7 5}+\mathbf{9 3 5 4 . 0 3 9} \mathbf{X}_{\mathbf{1}}-\mathbf{6 0 3 7 5 . 2 9}_{\mathbf{2}}+\mathbf{0 . 3 4 1 2 4 0}_{\mathbf{3}}+\mathbf{e} \\
& \text { Remarks: } \\
& \mathrm{Y}=\text { IHSG } \\
& \mathrm{X}_{1}=\text { Inflation rate } \\
& \mathrm{X}_{2}=\text { certificate of Bank Indonesia }(\mathrm{SBI}) \text { rate } \\
& \mathrm{X}_{3}=\text { IDR/USD exchange rate } \\
& \mathrm{e}=\text { Error rate }
\end{aligned}
$$

Based on the above regression equation, we get the following:

- Constanta is 3743.575 , meaning that without considering the other independent variables, the IHSG is fixed at 3743.575 .

- Value of regression coefficient $\mathrm{X}_{1}$ is 9354.039 , meaning that for every increase of one unit of inflation, the IHSG will increase 9354.039 unit with the assumption that the other independent variables are considered constant.

- Value of regression coefficient $\mathrm{X}_{2}$ is -60375.29 , meaning that for every increase of one unit of SBI rate, the IHSG at BEI will drop 60375.29 unit with the assumption that the other independent variables are considered constant.

- Value of regression coefficient $\mathrm{X}_{3}$ is 0.341240 , meaning that for every increase of one unit of IDR/USD exchange rate, the IHSG at BEI will increase 0.341240 unit with the assumption that the other independent variables are considered constant.

\section{Hypothesis Test}

a. T test

$\mathrm{T}$ Test was done by testing hypothesis 1,2 , and 3 using regression coefficient partially, to test whether there is significant impact of one independent variable on the dependent variable if the other independent variables are considered constant.

i. Hypothesis test 1 : inflation affects IHSG at BEI

Step I: hypothesis equation

$$
\begin{array}{ll}
\mathrm{H}_{0}: \mathrm{b}_{1}=0 & \begin{array}{l}
\text { (there is no significant impact of inflation on IHSG if the other } \\
\text { independent variables are considered constant). } \\
\mathrm{H}_{\mathrm{a} 1}: \mathrm{b}_{1} \neq 0
\end{array} \\
& \begin{array}{l}
\text { (there is significant impact of inflation on IHSG if the other } \\
\text { independent variables are considered constant). }
\end{array}
\end{array}
$$

Step II : real level $(\alpha=5 \%=0.05)$

Step III : statistical test value $($ sig $=0.0286)$

Step IV : Conclusion

Sig $<\alpha$, then $\mathrm{H}_{01}$ cannot be accepted, meaning there is significant impact of

inflation on IHSG if the other independent variables are considered constant).

ii. Hypothesis test 2 : certificate of Bank Indonesia (SBI) rate affects IHSG.

Step I : hypothesis equation 
$\mathrm{H}_{02}: \mathrm{b}_{2} \neq 0 \quad$ (there is no significant impact of SBI rate on IHSG if the other independent variables are considered constant).

$\mathrm{H}_{\mathrm{a} 2}: \mathrm{b}_{2} \neq 0 \quad$ (there is significant impact of SBI rate on IHSG if the other independent variables are considered constant).

Step II : real level $(\alpha=5 \%=0.05)$

Step III : statistical test value $($ sig $=0.0000)$

Step IV : Conclusion

$\mathrm{Sig}<\alpha$, then $\mathrm{H}_{02}$ cannot be accepted, meaning there is significant impact of SBI rate on IHSG if the other independent variables are considered constant)

iii. Hypothesis test 3 : IDR/USD exchange rate affects IHSG at BEI.

Step I : hypothesis equation

$$
\begin{array}{ll}
\mathrm{H}_{03}: \mathrm{b}_{3}=0 & \text { (there is no significant impact of IDR/USD exchange rate on } \\
& \text { IHSG if the other independent variables are considered } \\
& \text { constant). } \\
\mathrm{H}_{\mathrm{a} 3}: \mathrm{b}_{3} \neq 0 & \text { (there is significant impact of IDR/USD exchange rate on } \\
& \text { IHSG if the other independent variables are considered } \\
\text { constant). }
\end{array}
$$

Step II : real level $(\alpha=5 \%=0.05)$

Step III : statistical test value $(\mathrm{sig}=0.0000)$

Step IV : Conclusion

Sig $<\alpha$, then $\mathrm{H}_{03}$ cannot be accepted, meaning there is significant impact of IDR/USD exchange rate on IHSG if the other independent variables are considered constant).

b. F Test

F test was done by testing hypothesis 4 , using regression coefficients all together, to test whether there is significant impact of inflation, SBI rate, and exchange rate of IDR/USD all together on IHSG at BEI.

Hypothesis test 4: inflation, SBI rate, and exchange rate of IDR/USD affect IHSG at BEI.

Step I : Hypothesis Equation

$\mathrm{H}_{04}: \mathrm{b}_{1}=\mathrm{b}_{2}=\mathrm{b}_{3}=0$ (There is no impact of inflation, SBI rate, exchange rate of IDR/USD on IHSG at BEI).

$\mathrm{H}_{\mathrm{a} 4}: \mathrm{b}_{1} \neq \mathrm{b}_{2} \neq \mathrm{b}_{3} \neq 0$ (All together, inflation, SBI rate, exchange rate IDR/USD affect IHSG at BEI).

Step II : real level value $(\alpha=5 \%=0.05)$

Step III : statistical test value $(\mathrm{sig}=0.0000)$

Step IV : Conclusion

Sig $<\alpha$, then $\mathrm{H}_{04}$ cannot be accepted, thus all together inflation, SBI rate, and exchange rate of IDR/USD affect IHSG significantly at BEI.

\section{Discussion}

This research aims to test whether or not there is an impact of several variables such as inflation rate, certificate of Bank Indonesia (SBI) rate, and exchange rate of IDR/USD on the composite stock price index (IHSG) at BEI in the monthly periods of 2006- 2014.

The economic condition of a country cannot be seen directly from the stock market condition, but it can be seen from the share price index. The Indonesia stock market (BEI) condition can be seen from the performance of IHSG. Evolution of IHSG can help investors who will invest their capital in a company in investment decision making, whether it is going to be a profitable 
investment or not. Therefore, the evolution of IHSG is very important for the Indonesian economic growth.

After getting all necessary data for the classical assumption test, regression model is worth to be tested further, as it has met all assumption conditions in multicollinearity and auto-correlation. Then the regression model have been tested statistically through t-test, followed by f-test simultaneously.

Based on the result of partial test, it is found that inflation level gives significant impact on IHSG. That can be seen from the significant value $\leq$ real value, which is $0.000 \leq 0.05$. Also inflation level gives positive impact on IHSG. It can be seen the result of inflation level coefficient which is 9354.039. Theoretically, this is because inflation level is high so that the burden of the company also increases, causing the drop of company performance and will affect the profitability of the company. The drop of a company's profitability is bad news for traders in the stock market and can cause a drop in the stock price of that company and will also affect IHSG.

Based on this research, certificate of Bank Indonesia (SBI) rate has significant impact on IHSG. This can be seen from the significant value $\leq$ real level, which is $0.0286 \leq 0.05$. Also, SBI rate has negative impact on IHSG. That can be seen from SBI rate coefficient level which is 60375.29. Theoretically, low interest level will cause lower loan cost and will trigger investment and economic activity that cause stock price to increase and affect IHSG.

Based on the result of the research, exchange rate of IDR/USD has significant impact on IHSG. That can be seen from the significant value test $\leq$ real level, which is $0.0000 \leq 0.05$. Also, exchange rate of IDR/USD gives positive impact on IHSG because the traders are dominated by local companies, thus the transaction is only in IDR.

The result of simultaneous test shows that independent variables which are inflation rate, SBI rate and foreign exchange rate of IDR/USD have positive significant impact on IHSG in the period of 2006-2014 with confident level of $95 \%$. This can be seen from the significant value $\leq$ real value. That means changes in the inflation rate, SBI rate, and exchange rate of IDR/USD will affect IHSG. Those variables affect IHSG by $58,74 \%$, while other variables affect IHSG by $41,26 \%$.

From the above partial test result, it was found that there is positive and significant impact of inflation level to IHSG. Result of this research is equal with Hooker (2004) who stated that inflation level affects share price significantly. Case dan Fair (2002), found that inflation and stock price have a positive relation.

On the test of SBI rate, it was found that SBI rate has negative and significant impact on IHSG. That is supported by the research done by Lee (1992) in Maryati (2009). He found that interest rate has significant impact on IHSG.

On the foreign exchange test, it was found that IDR/USD exchange rate has positive impact on IHSG. This result is in line with the theory of Dornbusch and Fischer (1992) and similar to the result of previous researches. However, the result of this research shows that the impact of IDR/USD exchange rate on IHSG is significant, while the research by Suci (2012) found that IDR/USD exchange rate has causal relationship which is not significant on the stock price. The difference may be caused by different periods of the studies and different numbers of the data used. Additionally, there are other influencing factors namely the economic factor and the condition of the Indonesia stock market (BEI). 


\section{Conclusion}

Based on the research result we can have the following conclusions : (1) Inflation has positive significant impact on IHSG (2) Certificate of Bank Indonesia rate has negative significant impact on IHSG (3) Exchange rate of IDR/USD has positive significant impact on IHSG (4) Simultaneously, inflation, certificate of Bank Indonesia rate and exchange rate of IDR/USD affect IHSG at BEI in the period of 2006 - 2014. Those variables affect IHSG by 58,74\%, while other variables affect IHSG by $41,26 \%$.

\section{Managerial implication}

Managerial implications in this research are : (1) For investors in the capital market, based on the research result, several variables are affecting IHSG, such as inflation and SBI rate, that will provide information to the investors as a consideration for their investment, and it can be used as a reference in decision making to anticipate unwanted situations in investment (2) For researchers it is suggested to add and use more up to date variables and extend the period of the research.

\section{References}

Agus Widarjono.(2005). Ekonometrika: teori dan aplikasi untuk ekonomi dan bisnis.Yogyakarta: Ekonisia.

Ajija, Shochrul R dkk. (2011).Cara cerdas menguasai eviews. Jakarta : Salemba 4.

Aritonang, Lerbin R. (2002).Peramalan bisnis. Jakarta : Ghalia Indonesia. (2007).Riset pemasaran teori dan praktik. Jakarta: Ghalia Indonesia.

Aydemir Oguzhan dan Demirhan,erdal.(2009). The relationship between stock prices and exchanges rates evidence from Turkey. Euro journals, ISSN 1450-2887,23,207-215.

Dahlan Siamat.(2005).Manajemen lembaga keuangan.Jakarta:Universitas Indonesia.

Dornbusch, Rudiger, dan Stanley Fischer.(1992).Makroekonomi.Jakarta:Erlangga.

Damodar N. Gujarati.(2004).Basics econometrics. New York : Mc Graw Hill.

Fama,E.F. (1990). Stock returns, expected returns, and real activity. Journal of finance, 45, 1089-1108.

Frederic S.Mishkin, Stanley Eakins.(2000).Financial market and institution.New York : Pearson.

Hooker M. A. (2004). Macroeconomic Factors and Emerging Market Equity Returns: a Bayesian Model Selecting Approach. Emerging Markets Review, 5, 379-387.

Huzaimi Hussain \& Venus Khim-Sen Liew.(2004). "Causal relationships between exchange rates and stock prices in Malaysia and Thailand during the 1997 currency crisis turmoil," International Finance,Malaysia,04052015,EconWPA,36.

Jogiyanto.(2003).Teori portofolio dan analisis investasi, edisi kelima.Yogyakarta:BPFE.

Jones, Charles Parker. (2002).Investment:analysis and management. $8^{\text {th }}$ Edition. California : John Wiley and Sons, Inc.

Karl E.Case \& Fair.(2002).Macro economic principles.Fifth Edition.New Jersey:Prentice Hall, Inc.

Keown, Arthur J. et.al. (2002). Financial management principles and application : International Edition. $9^{\text {th }}$ Edition. New Jersey : Prentice Hall Inc.

Mankiw,N Gregory.(2000). Macroeconomic theory. Forth Edition.USA:Harvard University.

Muhammad Zuhdi Amin. (2012). Pengaruh tingkat inflasi, suku bunga SBI, nilai kurs dollar (USD/IDR), dan indeks dow jones (DJIA) terhadap pergerakan indeks harga saham gabungan di Bursa Efek Indonesia (BEI) (periode 2008-2011). Jurnal skripsi,Feb,71. 
Muradoglu G, K1vilcım M, Argae R (2001). Is there a long-run relationship between stock returns and monetary variables: evidence from and emerging market. Appl. finan. econ., 7 (6), 641-649.

Murtianingsih. (2012). Variabel Ekonomi Makro dan Indeks Harga Saham Gabungan. Jurnal manajemen dan Akuntasi,1,3, Desember 2012,22.

Nopirin. (1990). Ekonomi moneter. Edisi Pertama. Buku II. Yogyakarta : BPFE Yogyakarta.

Robi. (2008). Analisis portofolio optimal saham-saham LQ-45 pada periode agustus 2005-juli 2006 dengan metode single index model di Bursa Efek Jakarta. Busines and management journal Bunda Mulia,4,1,17

Roshinta Puspitaningrum Suhadak Zahroh Z.(2014). Pengaruh tingkat inflasi,tingkat suku bunga

SBI, dan pertumbuhan ekonomi terhadap nilai tukar rupiah, studi pada Bank Indonesia periode tahun 2003-2012. Jurnal administrasi bisnis (JAB),8,1,55.

Sri Maryanti. (2009). Analisis pengaruh nilai tingkat bunga SBI dan nilai kurs dollars AS terhadap Indeks Harga Saham Gabungan (IHSG). Pekbis jurnal,1,1,12-25.

Stephen A Ross, Randolph W.Westerfield, Bradrord D.Jordan.(2003). Corporate finance. New York:MC Graw Hill.

Sukirno, Sadono. (2004). Teori pengantar makroekonomi. Edisi Ketiga. Jakarta : Rajawali Pers Sunariyah.(2006).Pengantar pengetahuan pasar modal.Yogyakarta:UPP STIM YKPN.

Suparmoko, M. (1994). Pengantar ekonomika makro. Yogyakarta : BPFE Yogyakarta.

Suramaya Suci Kewal. (2012). Pengaruh inflasi, suku bunga, kurs, dan pertumbuhan PDB terhadap Indeks Harga Saham Gabungan. Jurnal economia, 8, 1,81.

Tandelilin,Eduardus.(2010).Portofolio dan investasi:teori dan aplikasi.Yogyakarta:Kanisius.

Werner Ria Murhadi.(2012).Determinan struktur modal:studi di Asia Tenggara. Journal of management and entrepreneurship,13,91-98.

Widoatmodjo,Sawidji.(2000).Cara sehat Investasi di pasar modal.Jakarta:Yayasan Mpu Ajar Artha. 